uted free of charge to all citizens of the State who apply for them. Specimens of agricultural products, when of public interest, are examined and reported upon free of charge. The board of directors is as follows: H. P. Armsby, Ph.D., director; William Frear, Ph.D., vice-director and chemist; William A. Buckhout, M.S., botanist ; George C. Butz, B.S., horticulturist ; William C. Patterson, superintendent of farm. Correspondence is invited, and inquiries upon agricultural matters will be answered as far as possible. Address Agricultural Experiment Station, State College, Centre County, Penn.

- We learn from Nature that in a Russian paper of Oct. 22 last, appears a preliminary report of the examination by Latschinof and Jerofeief, professors of mineralogy and chemistry respectively, of a meteoric stone weighing four pounds, which fell in the district of Krasnoslobodsk, Government of Pensa, Russia, on Sept. 4, I 886. In the insoluble residue, small corpuscles showing traces of polarization were observed. They are harder than corundum, and have the density and other characters of the diamond. The corpuscles are said to amount to one per cent of the meteoric stone. Carbon, in its amorphous graphitic form, has been long known as a constituent of meteoric irons and stones. Lately, small but well-defined crystals of graphitic carbon, having forms often presented by the diamond, were described as having been found in a meteoric iron from western Australia. If this supplementary discovery be confirmed, we may at last be placed on the track of the artificial production of the precious stone.

- The loss of electricity by a conductor in moist air, says $N a$ ture, has been lately studied by Signor Guglielmo (Turin Academy). He finds that with potentials less than 600 volts, moist air insulates as well as dry air, but with higher potentials there is more loss in moist air, and more the moister the air and the higher the potential. The potential at which the difference becomes perceptible is the same for a ball as for a fine point. It occurs with extremely smooth surfaces, and so cannot be attributed to discharges in consequence of roughness of surface. With equal potential, the loss of electricity has the same magnitude, whatever the dimensions of the balls used as conductors. In air saturated with vapors of insulating substances, the loss of electricity of a conductor is nearly the same as in dry air.

- According to Nature, frozen fish are now imported into France, and a society formed in Marseilles for the purpose of developing the trade (the Société du Trident) has a steamer and a sailing-vessel engaged in it. The steamer 'Rokelle' lately came into Marseilles with some 30,000 kilograms of frozen fish in its hold, the temperature of which is kept at $17^{\circ} \mathrm{C}$. below zero by means of a Pictet machine (evaporating sulphurous acid). The fish are caught with the net in various parts of the Mediterranean and Atlantic. After arrival they are despatched by night in a cold chamber. Experiment has shown that fish can be kept seven or eight months at low temperature without the least alteration. These fish are wrapped in straw or marine algæ, and have been sent on to Paris, and even to Switzerland.

- We learn from Nature that the fourth session of the International Geological Congress will be held next year in London. The congress was founded at a meeting of the American Association for the Advancement of Science, at Buffalo, in 1876 , the first session being held at Paris in 1878 , the second at Bologna in I88I, the third at Berlin in 1885 . The following is a list of the organizing committee appointed to carry out the arrangements: H. Bauerman; W. T. Blanford, F.R.S.; Rev. Prof. T. G. Bonney, F.R.S.; Prof. W. Boyd Dawkins, F.R.S.; John Evans, F.R.S.; Prof. W. H. Flower, F.R.S.; Arch. Geikie, F.R.S.; Prof. James Geikie, F.R.S.; Sir Douglas Galton, F.R.S.; Prof. A. H. Green, F.R.S.; Rev. Prof. S. Haughton, F.R.S.; Prof. T. H. Huxley, F.R.S.; W.H. Hudleston, F.R.S.; Prof. T. McK. Hughes; J. W. Hulke, F.R.S.; Prof. E. Hull, F.R.S.; Prof. J. W. Judd, F.R.S.; Prof. J. Prestwich, F.R.S.; F. W. Rudler; H. C. Sorby, F.R.S.; Sir W. W. Smyth, F.R.S.; W. Topley; Rev. Prof. Wiltshire; Henry Woodward, F.R.S. The duty of this committee will be to nominate the officers, to appoint executive committees, and to fix the exact date of meeting. The congress at Berlin requested that the meeting should be held in London between Aug. I 5 and Sept. I 5.
- The theory is advanced by Professor Mendeleef that petroleum is of mineral origin, and that its production is going on, and may continue almost indefinitely. Engineering states that he has succeeded in making it artificially by a process similar to that which he believes is going on in the earth, and experts find it impossible to. distinguish between the natural and the manufactured article. His hypothesis is that water finds its way below the crust of the earth, and then meets with carbides of metals, particularly of iron, in a glowing state. The water is decomposed into its constituent gases; the oxygen unites with the iron, while the hydrogen takes up the carbon, and ascends to a higher region, where part of it is condensed into mineral oil, and part remains as natural gas, to escape where it can find an outlet, or to remain stored at great pressure until a bore-hole is put down to provide it a passage to the surface. Oil-bearing strata occur in the vicinity of mountain ranges, and it is supposed that the upheaval of the hills has dislocated the strata below sufficiently to give the water access to depths from which it is ordinarily shut out. If the centre of the earth contains large amounts of metallic carbides, we have in prospect a store of fuel against the days when our coal will be exhausted.

- In 'Notice to Mariners,' No. 94, published by the United States Coast Survey, some very interesting information is given regarding the Gulf Stream. Between Rebecca Shoal and Cuba the current was found to vary in velocity, the maximum velocity arriving about nine hours and twenty minutes before the transit of the moon, and between Cuba and Yucatan the greatest velocity was. found at ten hours before the moon's transit. The greatest velocity of the current was observed fifty-one miles south of Rebecca Shoal, at which point the stream moved 3.73 knots per hour. Between Yucatan and Cuba the stream's greatest velocity was 6.32 knots, about thirty miles from Yucatan toward Cape San Antonio.

- The United States Coast Survey Steamer 'Blake,' Lieut. J. E. Pillsbury commanding, will continue the investigation of the Gulf Stream currents during the coming winter and spring months at the places mentioned below; and shipmasters, when in the vicinity, are requested to look out for and keep clear of her. During January and the first part of February the 'Blake' will be anchored about six hundred miles north-east of Barbadoes Islands, and in the track of vessels bound to the United States from the South Atlantic or off the South American coast to the eastward of Trinidad Island; the last part of February and until May, between the West India Islands, commencing at Trinidad, and ending at the old Bahama channel. When at anchor, she will hoist three balls from the foretopmast stay, and at night-time she will show from the same point three lights, - red, white, and red.

LETTERS TO THE EDITOR.

*** Correspondents are requested to be as brief as possible. The writer's name is in all cases required as proof of good faith.

Twenty copies of the number containing his communication will be furnished ree to any correspondent on request. The editor zvill be glad to publish any queries consonant with the character of
the journal.

Conspiracy of Silence.

I THINK your correspondent (Dec. I6, p. 298) is unjust to Professor Bonney, placing a meaning on his words which they will indeed bear, but which was not Professor Bonney's meaning. I am not a Darwinist, and have never accepted the Darwinian hypothesis so called ; and I can therefore dispassionately defend Professor Bonney. But I should like to volunteer a rather unnecessary: defence of men of science as a class, whether Darwinists or antiDarwinists, whom your correspondent attacks indiscriminately. 'Conspiracy' is an ugly word; and it is, as both Professor Huxley and Professor Bonney assert with good reason, not only an ugly word, but an improbable thing; and not only improbable, but (as. the scientific world is now constituted) impossible in a large way. A conspiracy within the limits of one scientific institution, to suppress a paper, may be planned and executed with some success by one or more of its officers and one or more of its members opposed to the writer of that paper. Thus far, but no farther, can a scientific conspiracy go. The thing has been often done, and will be often done; but it is a foolish thing to do, perfectly futile, injurious to the society in which it happens, and in the end injurious to the conspirators. But the writer of a paper, if it be a good one, can find many other ways of publishing it, without encountering a con- 
spiracy. If it be a poor paper, it will probably be suppressed several times before it gets published; and no one is to blame for that but its author. But a general conspiracy among men of science to suppress views because they are new, and unacceptable to old fogies, is impossible; and your correspondent and the Duke of Argyll must certainly know that fact; and it will remain a fact, in spite of any number of instances of special local repression that can be cited. When such repression happens, the fault lies with the man of new views, who will not or can not speak out boldly; who will not or can not make his conclusions irresistibly; who is too shy, or too limited in his personal associations, or too obscure in his language, to compel general attention to what he believes.

Younger men of science with new ideas seem to think that older men in science have no business of their own to attend to, but must drop all their personal investigations to discuss and investigate, prove or disprove, each new theory as soon as it is promulged. The fact is, every new presentation in any department of science is read with interest and attention by scores, hundreds, and in some rare cases by thousands, of experts working in that particular department. But, if it be an important new theory, it requires, on that account, to be carefully studied; which, of course, takes time, - months, sometimes years. The delay will always be in proportion, first to the importance, and second to the difficulty, of the subject-matter of the theory. The few whom it most interests are separately making up their minds about it, and consulting each other. The wisest and strongest minds take the longest time, resisting all pressure to force them to a premature conclusion. But there is a personal equation. Men of science differ greatly in their reticence and in their cautiousness. What is denounced by the author of the novelty, and by his friend or friends, as a conspiracy of silence, and a scandal to science, is in fact the involuntary cautiousness of men who know much and have been often mistaken; and it is the glory of science that it keeps its head level, as it keeps its eyes open and its heart warm. Let your correspondent reflect that there are two natural classes of men of science, - the daring and useful, and the cautious and useful. Both classes are equally useful and equally honorable; and the charge of a conspiracy of silence can no more justly be brought against the one class than the charge of a conspiracy of notoriety against the other.

Whenever "Mr. Bonney says that the scientific method is to wait, and not to investigate," I shall go to London to ask him what he can mean by such language; but if I have to wait until he actually says so foolish a word, I shall never again see London. In fact, Mr. Bonney never has said any thing of the sort, in the sense assigned to his words by your correspondent ; meaning by 'scientific method' the mode of pursuing truth proper for all the pursuers of truth. What he meant in his rebuke of the Duke of Argyll is evident : he meant that any one man of science not engaged in a given special line of research can not and dares not make up his own mind as to the validity of one of two opposing theories until those others who have that special line of research in hand have practically reached some consent on the subject.

Your correspondent's quotation from Professor Bonney (on p. 299, footnote) does him another injustice. Mr. Bonney writes, "Very well, but there are some people, not very few in number, who do not share the opinion." Your correspondent exclaims, "Hail to the new science! The voice of many people is the voice of God." But the people of Mr. Bonney are not the people of $\mathrm{Mr}$. Buel. Professor Bonney has said plainly enough that by 'people' he means such men as Darwin and Dana, the greatest investigators of these special coral phenomena. If Mr. Murray's 'people' are numerous, Mr. Darwin's and Mr. Dana's 'people' are also numerous. Most of the 'people' on both sides are of no value as reasoners on coral formation; but a few - a very few on both sides have some right to an opinion. But Mr. Huxley and Mr. Bonney do not claim to be of these few - on either side. Of course they wait.

It is a curious fact, and rather pathetic withal, that a man of science seldom or never opens his mouth but he puts his foot in it. At all events, there is always some half-man of science standing by ready to say so, and run for a doctor. But curious and even pathetic as the fact may be, it has its good and its bad consequences: it makes thoroughbred experts more cautious, both in framing their own opinions respecting the researches of others, and in expressing such opinions publicly; and it makes experts of the second, third, and fourth order of breeding correspondingly reckless in both thinking and speaking.

Philadelphia, Dec. 19 . J. P. LESLEY.

\section{A Wind-Register for Direction and Velocity.}

FOR some years it has been considered very important that not: only the total amount of wind should be recorded on self-registers, but that some simple means should be brought into use by which the recording sheet should give directly the number of miles or kilometres per hour of wind blowing from the various points of compass.

The plan usually adopted is to mark off on the velocity record the spaces of time during which the wind was blowing from the various quarters as indicated by the record sheet for the directions, or the direction is stamped on the velocity sheet at regular intervals. of time (say, every ten minutes) by the automatic closing of an electric circuit by means of a clock.

A method of registering the wind's velocity so as to give a minimum amount of labor in reading the recording sheet has suggested itself to me, and I have given below a short account of the principles of construction. I do not remember having seen mention of

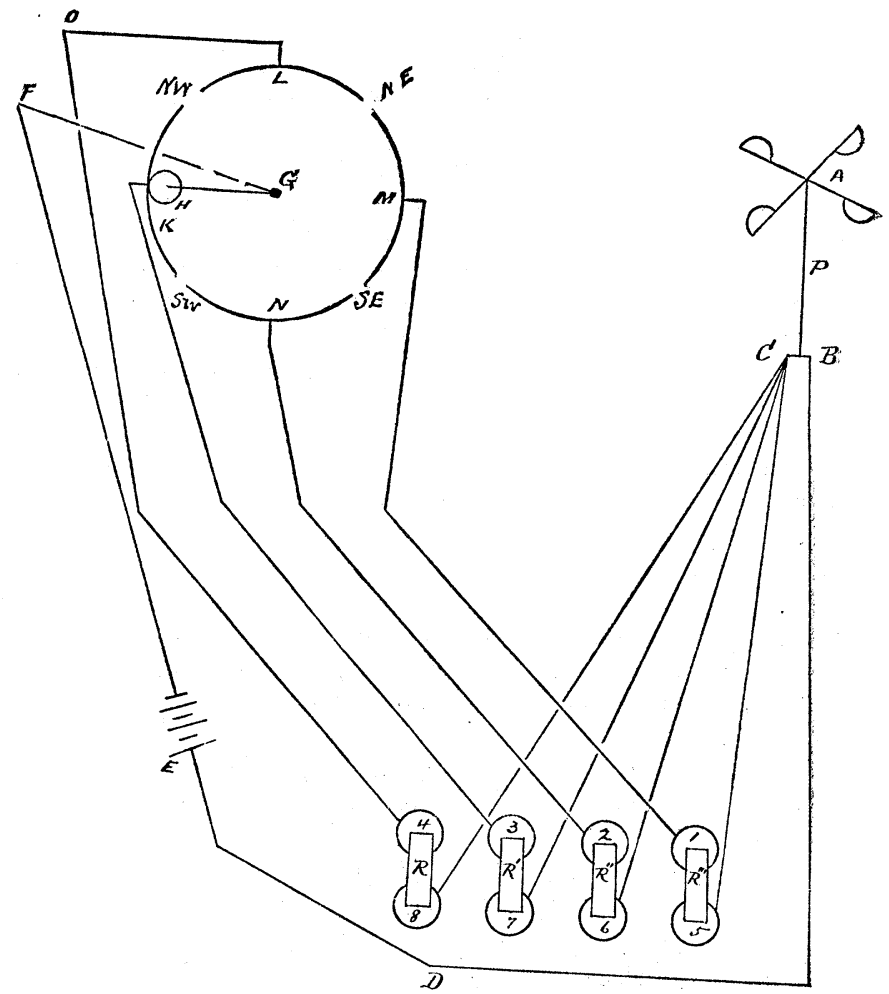

such an apparatus before, but it is so simple that it is probably not wholly new ; and a similar form of instrument may even be in actual use, but, if so, I cannot recall any such, and I am somewhat familiar with the instruments of the various meteorological observatories.

In the accompanying figure, $A$ represents the Robinson anemometer; $P$, the supporting frame; and $C$ and $B$, the posts to which the conducting wires are attached in the ordinary form of electrical self-registering anemometer, in which $C$ and $B$ have metallic connection through $P$ at the completion of each mile or kilometre of wind as shown by the anemometer dial: at other times the connection between $C$ and $B$ is broken. By means of a wire, $B$ is connected with one pole of the battery $E$. Wires also pass from $C$ to. binding-screws on $5,6,7,8$, electro-magnets of the recording apparatus.

The left-hand part of the diagram is shown in horizontal plan. $G$ is the lower end of a rod passing from the roof to the room beneath. This rod being in rigid connection with the wind-vane, it will revolve with the latter. Near the lower end of the rod, at $G$, an arm is placed at right angles to the rod, and terminates in the small friction-wheel $H$. 